\title{
Finite element analysis of lap joint through RSM technique
}

\author{
B. Stalin ${ }^{1 *}$, K. Vadivel $^{2}$, S. Saravanavel ${ }^{3}$ and M. Ravichandran ${ }^{4}$ \\ Assistant Professor, Department of Mechanical Engineering, Anna University, Regional Campus Madurai, \\ Keelakuilkudi, Madurai, Tamilnadu, India ${ }^{1}$ \\ PG Scholar, Department of Mechanical Engineering, Anna University, Regional Campus Madurai, Keelakuilkudi, \\ Madurai, Tamilnadu, India ${ }^{2}$ \\ Assistant Professor, Department of Mechanical Engineering, K. Ramakrishnan College of Engineering, \\ Tiruchirappalli, Tamilnadu, India ${ }^{3}$ \\ Associate Professor, Department of Mechanical Engineering, K. Ramakrishnan College of Engineering, \\ Tiruchirappalli, Tamilnadu, India ${ }^{4}$

\section{(C)2018 ACCENTS}

\begin{abstract}
Welding technology is one of the fastest growing opportunities in the field of manufacturing engineering. Today, many construction, erection, ship building and body building works are not possible without welding. Although welding technology has many positive features, there are some negative features which are to be taken under consideration of this work. Many risks and accidents could be avoided, if the negative features of welding technology have been rectified. Many people involving in welding works are not able to identify the exact loading and boundary conditions for the corresponding weld, which is to be created by using design of experiment (DOE). So that, improper welding as well as lack of knowledge about the necessary welding parameters, has led to many accidents. This paper deals with the analytical response approaches of lap joint weld with respect to the minimum and maximum loading parameters. In order to identify the boundary condition of mechanical parameters with respect to the weld which is to be created. Hence the products which are designed the suggested load and dimensional specifications would follow the mechanical parameters which are obtained analytically by using ANSYS in order to avoid the percentage of risk and accidents in future. Aiding an improvement in the performance of work for the growth in future, for the betterment of people welfare and the environment in our society.
\end{abstract}

\section{Keywords}

Response surface methodology, Design of experiment, Spot welding, Lab joint, Finite element analysis.

\section{Introduction}

Welding is the processes of joining materials together by fusion. In the present work we are going to discuss about spot welding which is the resistant welding method which is used to join overlapping sheet metals up to $3 \mathrm{~mm}$ thickness. The term resistant welding refers to the generation of heat by passing the current through the resistance caused by the contact between two or more metal surfaces. The model of the spot welded lap joint is to be analyzed for identifying its mechanical properties with respect to the load and boundary conditions.

In order to perform work on the design of experiments and attain the results.

\footnotetext{
*Author for correspondence
}

Khana et al. [1] have performed work on knowledge visualization framework in resistance spot welding to visualize the design of weldment along with the visualization knowledge. Dong et al. [2] had conducted a time variant fatigue reliability test by PHI2 and response surface methods on a T-plate welded joint subjected to stochastic loading, to solve the time variant problems. Kermanidis et al. [3] have created laser spot welded joints in order to evaluate its mechanical performance, which is used in thermal absorber systems. Kumar et al. [4] have conducted analysis in TIG spot weld for bonding ferritic stainless steel in order to absorb the characteristics of welds bond. Long et al. [5] Performed parametric optimization on laser welding using the Taguchi response surface method. Martinez-Conesa et al. [6] performed optimization in a welded joint through response surface method with its geometrical parameters. Shanavas and Dhas [7] used response 
surface method to perform parametric optimization in friction stir welding parameters. Vedrtnam et al. [8] performed optimization on submerged arc welding using response surface method, regression analysis and genetic algorithms. Song et al. [9] reduced the weight of upper control arm which is used in automobile by using of Kriging model and response surface method. Wang et al. [10] performed response surface optimization in distillation column having some operating parameters as its input. Ganesamoorthi et al. [11] performed optimization with a response surface method for ultrasonic metal welding of copper sheet and copper wire. Kumar and Patil [12] performed parametric optimization with response surface method and FEA stimulation on the gearbox housing to control vibration in transmission systems.

The work on analytical response of lap joints through design of experiments is to identify the necessary minimum and maximum boundary conditions of mechanical parameters so that the products which are designed within the safety constraints without disturbing the environment. In other words, these methods would help us to come with finding some standards and specifications for the corresponding weld which is to be created (Figure 1).

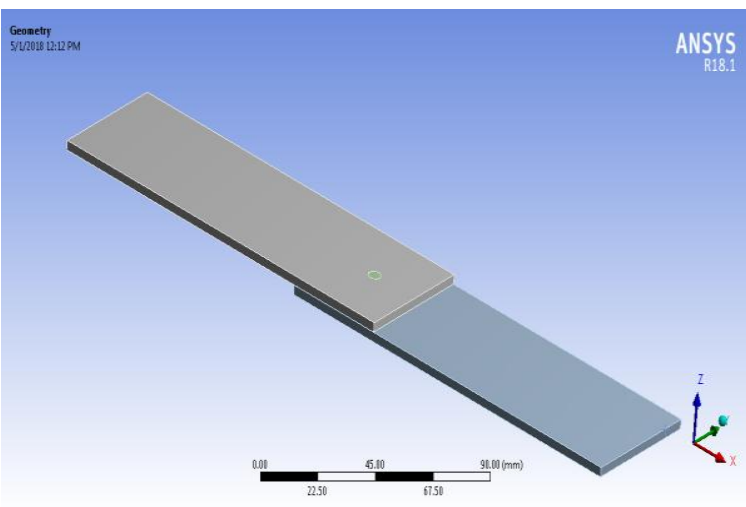

Figure 1 Model of the welded plates

\section{Materials and methodology \\ 2.1Geometrical specification}

The product which is to be analyzed is to be checked for its geometrical specifications, since we are conducting spot weld on lap joints the material thickness for each overlapping plate is suggested to be $3 \mathrm{~mm}$, since the spot weld diameter with consideration to thickness should not exceed $3 \mathrm{~mm}$. The weld diameter is assumed to be $5 \mathrm{~mm}$. The overlapping plate (Figure 2) is 155:50 ratios and the overlapping length is 40:50 ratios. The represented in the below drafting follows first angle projection and material properties presented in Table 1 .

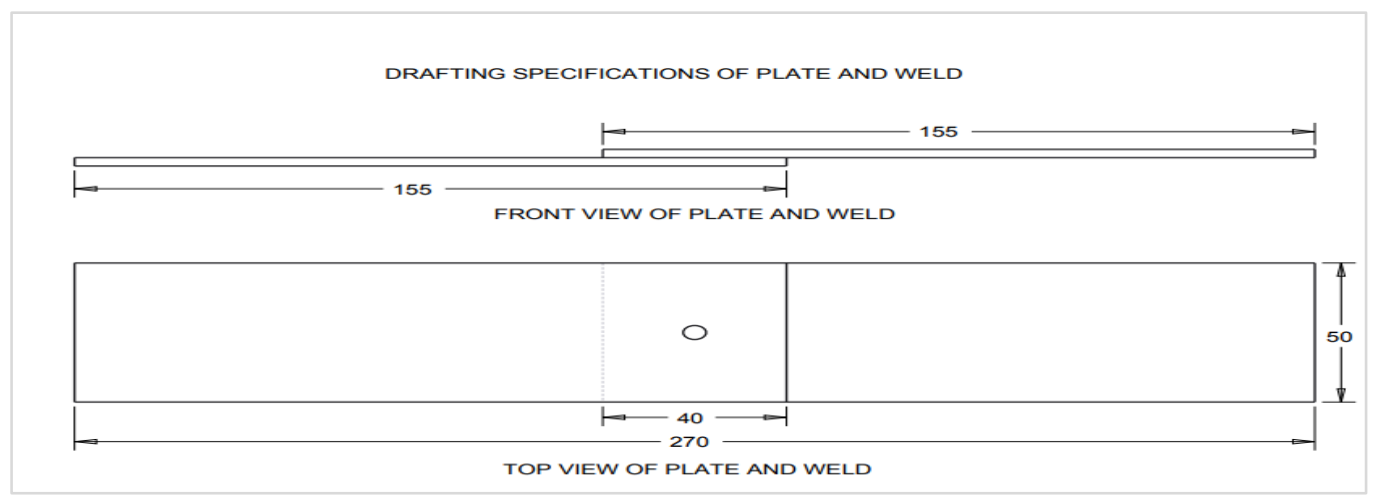

Figure 2 Geometrical specification

Table 1 Material properties

\begin{tabular}{ll}
\hline Properties & Values \\
\hline Young's modulus (E) & $2 \mathrm{E}^{11} \mathrm{~Pa}$ \\
Density $(\rho)$ & $7850 \mathrm{~kg} / \mathrm{m}^{3}$ \\
Poisson's Ratio & 0.3 \\
Tensile strength & $744.6 \times 10^{6} \mathrm{~Pa}$ \\
Yield strength & $472.3 \times 10^{6} \mathrm{~Pa}$ \\
\hline
\end{tabular}

\subsection{Procedure for analysis}

The procedure for the analysis of lap joint are listed below;

- Create a model.

441
- Import the model into analytical environment.

- Set some load and boundary condition.

- Undergoes the static structural analysis.

- Share the structural analysis report.

- Along with the response surface workspace

- Procedure design of experiment with some input parameters.

- Retrieve the minimum and maximum output parameters and form the boundary conditions.

The procedural analysis tree diagram is shown in Figure 3. 
Stalin et al.

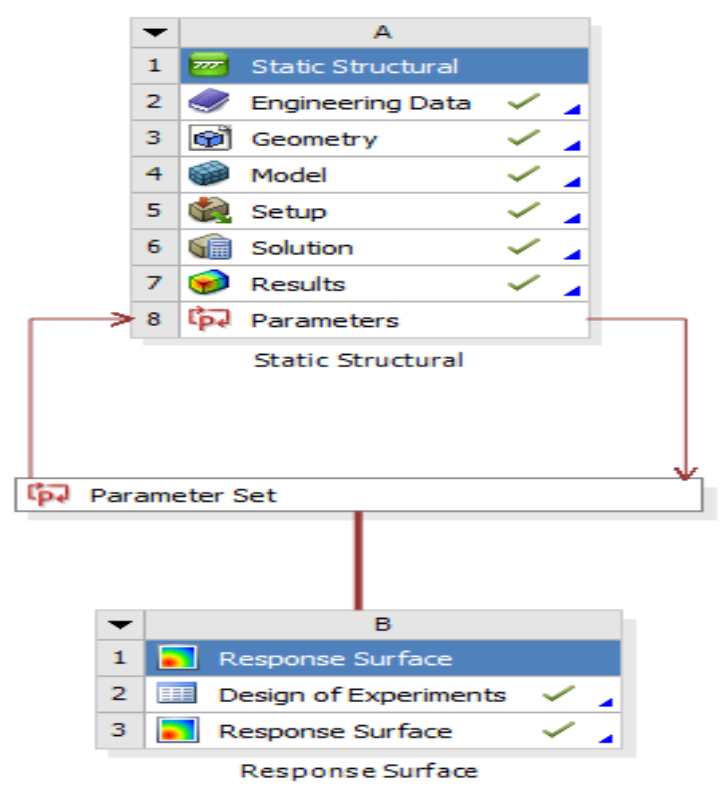

Figure 3 Analysis tree diagram

\subsection{Design of experiment methodology}

In this paper, we are undergoing a process of response surface optimization were the force component in $\mathrm{x}, \mathrm{y} \& \mathrm{z}$ axis is considered as the mechanical properties such as an equivalent stress minimum, Equivalent stress maximum, Total deformation minimum, Total deformation maximum, Direction deformation minimum, Direction deformation maximum, Equivalent elastic strain minimum and Equivalent elastic strain maximum are considered as output parameters.

Usually the analytical method for some simple static loading would have single dimensional force as an input parameter analysis. But in real time the effect of force along a single dimension would have its corresponding effect along other two dimensions. The result reveals the status of the force component with the effect of alternative resultant forces which can be experienced in real time input parameter which is taken under consideration the output parameters are observed through conducting design of experiments. This output parameter will have some minimum and maximum response which is considered to be a boundary condition for the mechanical parameters in the concerned product. The DOE methodology for lap joint is presented in Table 2 and variation of mechanical properties is shown in Figure 4.

Table 2 DOE table for lap joint

\begin{tabular}{|c|c|c|c|c|c|c|c|c|c|c|c|c|}
\hline $\begin{array}{l}\text { Sl.n } \\
\text { o. }\end{array}$ & $\begin{array}{l}\text { Force } x \\
\text { compo } \\
\text { nent }\end{array}$ & $\begin{array}{l}\text { Force y } \\
\text { compo } \\
\text { nent }\end{array}$ & $\begin{array}{l}\text { Force } z \\
\text { compo } \\
\text { nent }\end{array}$ & $\begin{array}{l}\text { Equiva } \\
\text { lent } \\
\text { stress } \\
\text { minim } \\
\text { um }\end{array}$ & $\begin{array}{l}\text { Equiva } \\
\text { lent } \\
\text { stress } \\
\text { maxim } \\
\text { um }\end{array}$ & $\begin{array}{l}\text { Total } \\
\text { deforma } \\
\text { tion } \\
\text { minimu } \\
\text { m }\end{array}$ & $\begin{array}{l}\text { Total } \\
\text { deforma } \\
\text { tion } \\
\text { maximu } \\
\text { m }\end{array}$ & $\begin{array}{l}\text { Directio } \\
\text { nal } \\
\text { deforma } \\
\text { tion } \\
\text { minimu } \\
\text { m } \\
\end{array}$ & $\begin{array}{l}\text { Directio } \\
\text { nal } \\
\text { deforma } \\
\text { tion } \\
\text { maximu } \\
\text { m } \\
\end{array}$ & $\begin{array}{l}\text { Equiva } \\
\text { lent } \\
\text { elastic } \\
\text { strain } \\
\text { minim } \\
\text { um } \\
\end{array}$ & $\begin{array}{l}\text { Equiva } \\
\text { lent } \\
\text { elastic } \\
\text { strain } \\
\text { maxim } \\
\text { um } \\
\end{array}$ & $\begin{array}{l}\text { Safet } \\
\mathbf{y} \\
\text { facto } \\
\mathbf{r}\end{array}$ \\
\hline 1 & 5 & 5 & 100 & 0.49434 & 383.32 & 0 & 25.702 & 0 & 25.696 & $\begin{array}{l}7.556 \mathrm{E}- \\
6\end{array}$ & $\begin{array}{l}0.00191 \\
68\end{array}$ & $\begin{array}{l}0.652 \\
2\end{array}$ \\
\hline 2 & 0 & 5 & 100 & 0.49786 & 383.13 & 0 & 25.386 & 0 & 25.68 & $\begin{array}{l}7.560 \\
\text { E-6 }\end{array}$ & $\begin{array}{l}0.00191 \\
59\end{array}$ & $\begin{array}{l}0.652 \\
52\end{array}$ \\
\hline 3 & 10 & 5 & 100 & 0.49176 & 383.5 & 0 & 25.718 & 0 & 25.712 & $\begin{array}{l}7.555 \\
\text { E-6 }\end{array}$ & $\begin{array}{l}0.00191 \\
78\end{array}$ & $\begin{array}{l}0.651 \\
89\end{array}$ \\
\hline 4 & 5 & 0 & 100 & 0.48316 & 382.26 & 0 & 25.702 & 0 & 25.696 & $\begin{array}{l}7.599 \\
\text { E-6 }\end{array}$ & $\begin{array}{l}0.00191 \\
16\end{array}$ & 0.654 \\
\hline 5 & 5 & 10 & 100 & 0.52395 & 384.46 & 0 & 23.133 & 0 & 25.696 & $\begin{array}{l}7.489 \\
\text { E-6 }\end{array}$ & $\begin{array}{l}0.00192 \\
26\end{array}$ & $\begin{array}{l}0.650 \\
26\end{array}$ \\
\hline 6 & 5 & 5 & 90 & 0.44635 & 345.12 & 0 & 28.27 & 0 & 23.128 & $\begin{array}{l}6.793 \\
\text { E-6 }\end{array}$ & $\begin{array}{l}0.00172 \\
58\end{array}$ & $\begin{array}{l}0.724 \\
39\end{array}$ \\
\hline 7 & 5 & 5 & 110 & 0.54249 & 421.51 & 0 & 23.6 & 0 & 28.264 & $\begin{array}{l}8.3189 \\
\text { E-6 }\end{array}$ & $\begin{array}{l}0.00210 \\
79\end{array}$ & $\begin{array}{l}0.593 \\
1\end{array}$ \\
\hline 8 & 0.93483 & 0.93483 & 91.87 & 0.4436 & 351.17 & 0 & 23.627 & 0 & 23.595 & $\begin{array}{l}6.9972 \\
\text { E-6 }\end{array}$ & $\begin{array}{l}0.00175 \\
61\end{array}$ & $\begin{array}{l}0.711 \\
9\end{array}$ \\
\hline 9 & 9.0652 & 9.0652 & 91.87 & 0.45133 & 351.58 & 0 & 23.6 & 0 & 23.621 & $\begin{array}{l}6.9914 \\
\text { E-6 }\end{array}$ & $\begin{array}{l}0.00210 \\
79\end{array}$ & $\begin{array}{l}0.711 \\
08\end{array}$ \\
\hline 10 & 0.93483 & 0.93483 & 91.87 & 0.48794 & 353.04 & 0 & 23.627 & 0 & 23.595 & $\begin{array}{l}6.8829 \\
\text { E-6 }\end{array}$ & $\begin{array}{l}0.00175 \\
61\end{array}$ & $\begin{array}{l}0.708 \\
14\end{array}$ \\
\hline 11 & 9.0652 & 9.0652 & 91.87 & 0.47262 & 353.34 & 0 & 27.777 & 0 & 23.622 & $\begin{array}{l}6.8833 \\
\text { E-6 }\end{array}$ & $\begin{array}{l}0.00176 \\
54\end{array}$ & $\begin{array}{l}0.707 \\
53\end{array}$ \\
\hline 12 & 0.93483 & 0.93483 & 108.13 & 0.52171 & 413.29 & 0 & 27.803 & 0 & 27.771 & $\begin{array}{l}8.2349 \\
\text { E-6 }\end{array}$ & $\begin{array}{l}0.00176 \\
7\end{array}$ & $\begin{array}{l}0.604 \\
9\end{array}$ \\
\hline 13 & 9.0652 & 9.0652 & 108.13 & 0.52851 & 413.7 & 0 & 27.777 & 0 & 27.797 & 8.229 & 0.00206 & 0.604 \\
\hline
\end{tabular}


International Journal of Advanced Technology and Engineering Exploration, Vol 5(48)

\begin{tabular}{|c|c|c|c|c|c|c|c|c|c|c|c|c|}
\hline $\begin{array}{l}\text { Sl.n } \\
\text { o. }\end{array}$ & $\begin{array}{l}\text { Force } x \\
\text { compo } \\
\text { nent }\end{array}$ & $\begin{array}{l}\text { Force } \mathbf{y} \\
\text { compo } \\
\text { nent }\end{array}$ & $\begin{array}{l}\text { Force } z \\
\text { compo } \\
\text { nent }\end{array}$ & $\begin{array}{l}\text { Equiva } \\
\text { lent } \\
\text { stress } \\
\text { minim } \\
\text { um }\end{array}$ & $\begin{array}{l}\text { Equiva } \\
\text { lent } \\
\text { stress } \\
\text { maxim } \\
\text { um }\end{array}$ & $\begin{array}{l}\text { Total } \\
\text { deforma } \\
\text { tion } \\
\text { minimu } \\
\text { m }\end{array}$ & $\begin{array}{l}\text { Total } \\
\text { deforma } \\
\text { tion } \\
\text { maximu } \\
\text { m }\end{array}$ & $\begin{array}{l}\text { Directio } \\
\text { nal } \\
\text { deforma } \\
\text { tion } \\
\text { minimu } \\
\text { m }\end{array}$ & $\begin{array}{l}\text { Directio } \\
\text { nal } \\
\text { deforma } \\
\text { tion } \\
\text { maximu } \\
\text { m }\end{array}$ & $\begin{array}{l}\text { Equiva } \\
\text { lent } \\
\text { elastic } \\
\text { strain } \\
\text { minim } \\
\text { um } \\
\end{array}$ & $\begin{array}{l}\text { Equiva } \\
\text { lent } \\
\text { elastic } \\
\text { strain } \\
\text { maxim } \\
\text { um }\end{array}$ & $\begin{array}{l}\text { Safet } \\
y \\
\text { facto } \\
\mathbf{r}\end{array}$ \\
\hline 14 & 0.93483 & 0.93483 & 108.13 & 0.56121 & 415.15 & 0 & 27.803 & 0 & 27.771 & $\begin{array}{l}\text { E-6 } \\
8.123 \\
\text { E-6 }\end{array}$ & $\begin{array}{l}67 \\
0.00206 \\
88\end{array}$ & $\begin{array}{l}31 \\
0.602 \\
19\end{array}$ \\
\hline 15 & 9.0652 & 9.0652 & 108.13 & 0.54811 & 415.46 & 0 & 27.777 & 0 & 27.797 & $\begin{array}{l}8.1213 \\
\text { E-6 }\end{array}$ & $\begin{array}{l}0.00207 \\
76\end{array}$ & $\begin{array}{l}0.601 \\
75 \\
\end{array}$ \\
\hline
\end{tabular}

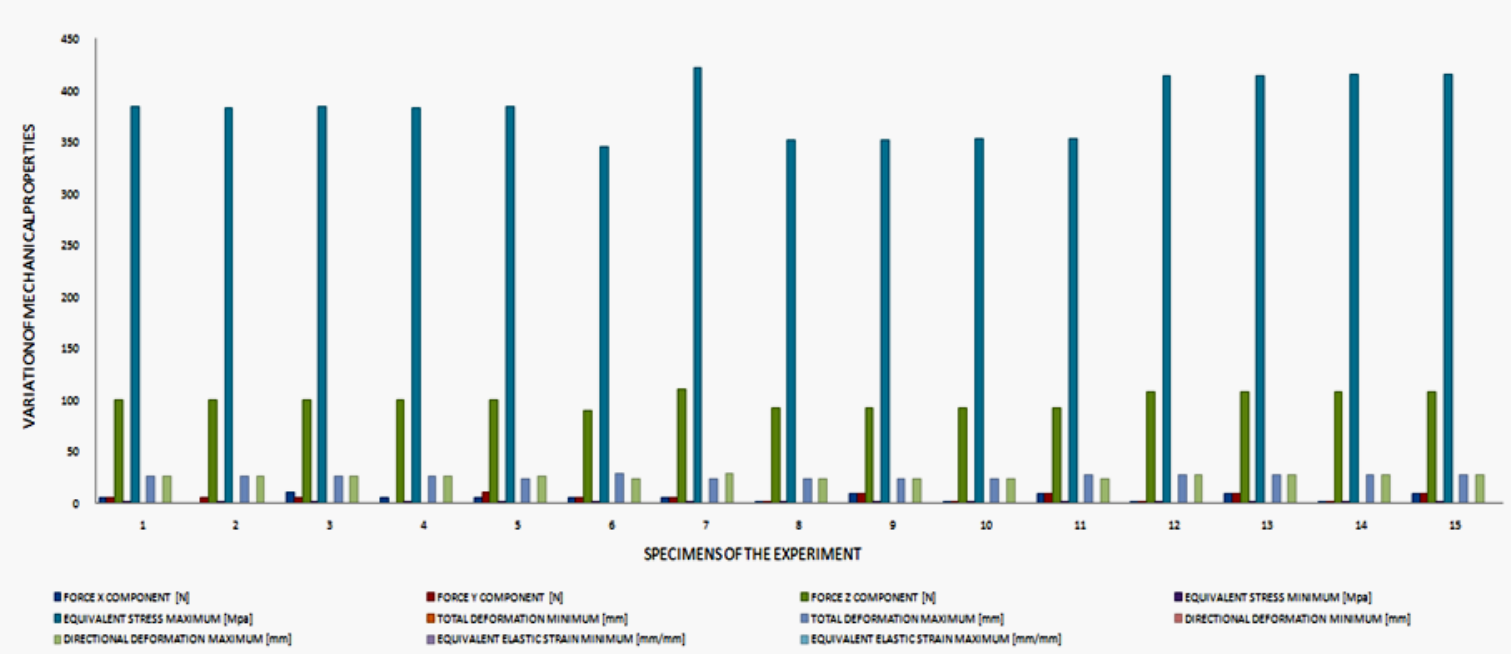

Figure 4 Variation of mechanical properties by DOE methodology

\section{Results and discussion}

The product which is imported into the response surface workspace is to be set for its upper and lower boundary value which is the input parameter for corresponding analytical experiments. Here we consider force as an input parameter with $0 \mathrm{~N}$ and $10 \mathrm{~N}$ as its lower and upper boundary value along the $\mathrm{x}$ and $\mathrm{y}$ axis while considering $\mathrm{z}$ axis the lower and upper boundary values are $90 \mathrm{~N}$ and $110 \mathrm{~N}$ which is taken under consideration for conducting experiments. The results are converged by comparing the results between the above fifteen output mechanical parameters.

\subsection{0utput parameters}

The output parameters of equivalent stress, total deformation, directional deformation, equivalent elastic strains are presented in the Table 3.

Table 3 Output parameters

\begin{tabular}{ll}
\hline Parameter & Value \\
\hline Equivalent stress minimum & 0.48309 \\
\hline Equivalent stress maximum & 382.5 \\
\hline Total deformation minimum & 0 \\
\hline Total deformation maximum & 25.686 \\
\hline Directional deformation minimum & 0 \\
\hline Directional deformation maximum & 25.68 \\
\hline Equivalent elastic strain minimum & $7.599 \mathrm{E}-6$ \\
\hline Equivalent elastic strain maximum & 0.0019104 \\
\hline
\end{tabular}

\section{Conclusions}

The major objective of this work is to follow design of experiment frameworks that are the boundary conditions. So, that the product welded within the parameter in the boundary condition would be safe without disturbing the environment. The outputs of 
response surface analysis (RSA) are consistent with the DOE outputs have feasible of RSM. The output of this work suggests that the simulation process running in the safe environment is shown in Table 3. The analysis is carried out for varying loads in three different axis by keeping the geometrical and dimensional parameters constant. The mechanical properties of fifteen output parameters are compared with is a safety factor, while comparing the output parameters a maximum safety factor of 0.72439 is obtained for the loads of $5 \mathrm{~N}$ in $\mathrm{x}$ and $\mathrm{y}$ axis, $90 \mathrm{~N}$ in $\mathrm{z}$ axis which is one of the input value of the above fifteen output parameters.

- It is used in Bhurj Khalifa building eructation works for structure analysis.

- It is used in fabrication of chassis in automobile industries.

For the future continuation of this work, optimization of geometric parameters in a welded joint through response surface methodology to be investigated in automobile applications.

\section{Acknowledgment}

The authors thank the Department of Mechanical Engineering, Anna University, Regional Campus Madurai for providing partial support for carrying out this research work.

\section{Conflicts of interest}

The authors have no conflicts of interest to declare.

\section{References}

[1] Khan MT, Ahmed F, Kim KY. Weldability knowledge visualization of resistance spot welded assembly design. Procedia Manufacturing. 2017; 11:1609-16.

[2] Dong Y, Teixeira AP, Soares CG. Time-variant fatigue reliability assessment of welded joints based on the PHI2 and response surface methods. Reliability Engineering \& System Safety. 2018; 177:120-30.

[3] Kermanidis AT, Christodoulou PI, Hontzopoulos E, Haidemenopoulos GN, Kamoutsi H, Zervaki AD. Mechanical performance of laser spot-welded joints in $\mathrm{Al}-\mathrm{Al} / \mathrm{Cu}$ solar thermal absorbers. Materials \& Design. 2018; 155:148-60.

[4] Kumar A, Sharma G, Dwivedi DK. TIG spot weld bonding of $409 \mathrm{~L}$ ferritic stainless steel. International Journal of Adhesion and Adhesives. 2018; 84:350-9.

[5] Long J, Huang W, Xiang J, Guan Q, Ma Z. Parameter optimization of laser welding of steel to $\mathrm{Al}$ with preplaced metal powders using the Taguchi-response surface method. Optics \& Laser Technology. 2018; 108:97-106.

[6] Martinez-Conesa EJ, Egea JA, Miguel V, Toledo C, Meseguer-Valdenebro JL. Optimization of geometric parameters in a welded joint through response surface methodology. Construction and Building Materials. 2017; 154:105-14.
[7] Shanavas S, Dhas JE. Parametric optimization of friction stir welding parameters of marine grade aluminium alloy using response surface methodology. Transactions of Nonferrous Metals Society of China. 2017; 27(11):2334-44.

[8] Vedrtnam A, Singh G, Kumar A. Optimizing submerged arc welding using response surface methodology, regression analysis, and genetic algorithm. Defence Technology. 2018; 14(3):204-12.

[9] Song XG, Jung JH, Son HJ, Park JH, Lee KH, Park YC. Metamodel-based optimization of a control arm considering strength and durability performance. Computers \& Mathematics with Applications. 2010; 60(4):976-80.

[10] Wang H, Cui X, Wang R, Li C. Response surface optimization of the operating parameters for a complex distillation column based on process simulation. Energy Procedia. 2012; 16:571-8.

[11] Ganesamoorthi B, Kalaivanan S, Dinesh R, Anand K. Optimization technique using response surface method for USMW process. Procedia-Social and Behavioral Sciences. 2015; 189:169-74.

[12] Kumar A, Patil PP. FEA simulation and RSM based parametric optimisation of vibrating transmission gearbox housing. Perspectives in Science. 2016; 8:388-91.

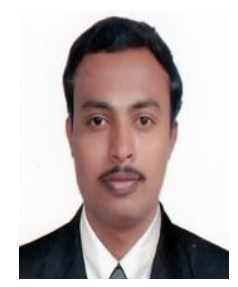

Stalin. B was born in Virudhunagar District, Tamilnadu, India, in 1981. He received B.E. Degree in Mechanical Engineering from the University of Madras, Tamilnadu, India, in 2002, and M.E. Degree in Manufacturing Engineering from the Anna University, Tamilnadu, India, in 2008. He obtained his Ph.D in Mechanical Engineering discipline, in 2015 at Anna University, Chennai, Tamilnadu, India. He has been currently working as an Assistant Professor in the Department of Mechanical Engineering, Anna University, Regional Campus Madurai, Tamilnadu, India since 2010. $\mathrm{He}$ is a Life Member of the Indian Society for Technical Education (ISTE) and The Institution of Engineers (India). His current research interests include Optimization Technology, Manufacturing Engineering, Composite Materials, Material Characterization, and Mechanical Properties.

Email: stalin1312@gmail.com

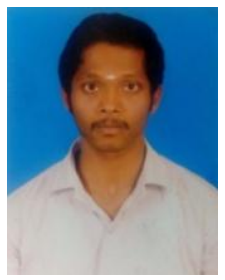

K.Vadivel was born in Vedasandur, Dindigul district, Tamilnadu, India, in 1996. He received B.E Degree in Mechanical Engineering at Angel College of Engineering and Technology in Tirupur, India, 2017. He is currently pursuing Master of Engineering in Department of

Mechanical Engineering, Anna University, Regional Campus Madurai, Tamilnadu, India since 2018. His areas of interest are Design and Analysis of Mechanical Component, Manufacturing Technology and Optimization Technology. 